\title{
Transfer of Rhodococcus aichiensis Tsukamura 1982 and Nocardia amarae Lechevalier and Lechevalier 1974 to the Genus Gordona as Gordona aichiensis comb. nov. and Gordona amarae comb. nov.
}

\author{
STEFAN KLATTE, ${ }^{*}$ FRED A. RAINEY, AND REINER M. KROPPENSTEDT \\ DSM-Deutsche Sammlung von Mikroorganismen und Zellkulturen GmbH, \\ D-38124 Braunschweig, Germany
}

\begin{abstract}
We investigated the taxonomic status of Rhodococcus aichiensis $\mathrm{DSM} 43978^{\mathrm{T}}(\mathrm{T}=$ type strain) and Nocardia amarae DSM $43392^{\mathrm{T}}$ by using both chemotaxonomic and genetic methods. The occurrence of $\mathrm{MK}-9\left(\mathrm{H}_{2}\right)$ as the predominant menaquinone, the presence of relatively long-chain mycolic acids (48 to 62 carbon atoms), and the phylogenetic position as determined by a $16 \mathrm{~S}$ ribosomal DNA sequence analysis provide strong evidence that both $R$. aichiensis and $N$. amarae should be transferred to the genus Gordona as Gordona aichiensis and Gordona amarae, respectively.
\end{abstract}

The taxonomy of actinomycetes containing mycolic acids (high-molecular-weight $\alpha$-branched 3-hydroxy fatty acids) has been markedly changed by the use of numerical taxonomic, chemical, and molecular systematic methods $(3,4)$. Although such investigations have revealed several morphological and chemical markers that distinguish members of this suprageneric group $(18,24-26)$, which comprises the genera Corynebacterium, Gordona, Mycobacterium, Nocardia, Rhodococcus, and Tsukamurella, there are still a few taxa whose classification is uncertain. Two such taxa, Nocardia amarae (16) and Rhodococcus aichiensis (27), have been retained in the genera Nocardia and Rhodococcus, respectively; however, the current affiliations of these species are in some respects contradictory to the diagnostic characteristics of the respective type species. Several analyses of the type strain of $N$. amarae have revealed notable differences between this organism and authentic nocardiae with respect to sensitivity to nocardiophages (28) and lysozyme $(5,16)$, serological cross-reactions $(22)$, and the presence of MK-9 $\left(\mathrm{H}_{2}\right)$ as the major menaquinone (5). Furthermore, the results of rRNA-DNA pairing experiments (18) and numerical phenetic analyses $(5,19)$ have revealed that there is only a loose relationship between $N$. amarae and the genus Nocardia sensu stricto. Classification of $R$. aichiensis in the genus Rhodococcus is also open to question. The occurrence of $\mathrm{MK}-9\left(\mathrm{H}_{2}\right)$ as the predominant isoprenolog and mycolic acids having an average chain length of 62 carbon atoms clearly distinguishes $R$. aichiensis from all other rhodococci except Rhodococcus chubuensis, which also is considered a species incertae sedis (3). The aims of this study were to clarify the taxonomic positions of $N$. amarae and $R$. aichiensis and to investigate the phylogenetic coherence of the genus Gordona.

\section{MATERIALS AND METHODS}

Bacterial strains and growth conditions. For chemical and genetic analyses, $R$. aichiensis DSM $43978^{\mathrm{T}}$ ( $\mathrm{T}=$ type strain), $N$. amarae DSM $43392^{\mathrm{T}}$, and Gordona sputi DSM $43986^{\mathrm{T}}$ were

\footnotetext{
${ }^{*}$ Corresponding author. Mailing address: DSM-Deutsche Sammlung von Mikroorganismen und Zellkulturen $\mathrm{GmbH}$, Mascheroder Weg 1B, D-38124 Braunschweig, Germany. Phone: 49-531-2616-225. Fax: 49-531-2616-418.
}

grown either in shake flasks containing Trypticase soy broth (BBL) or on Trypticase soy broth agar for 4 days at $28^{\circ} \mathrm{C}$.

Cell chemistry. An analysis of the isoprenoid quinones, polar lipids, cell wall diamino acids, and sugars of $P$. aichiensis DSM $43978^{\mathrm{T}}$ was carried out by using previously described methods $(10,14,15)$. The fatty acid methyl esters obtained from wet biomass preparations (approximately $40 \mathrm{mg}$ ) of $R$. aichiensis DSM $43978^{\mathrm{T}}$ and $G$. sputi DSM $43896^{\mathrm{T}}$ were analyzed and identified by gas chromatography, using a model 5898A Microbial Identification System apparatus (Microbial ID, Newark, Del.) as described previously (23).

$16 S$ rDNA sequencing. Genomic DNA was isolated and PCR-mediated amplification of the $16 \mathrm{~S}$ ribosomal DNA (rDNA) was performed as described by Rainey et al. (21). Double-stranded PCR products were sequenced by using a Taq Dye-Deoxy Terminator Cycle sequencing kit (Applied Biosystems) and the protocol recommended by the manufacturer. Sequence reaction mixtures were electrophoresed by using an Applied Biosystems model 373A DNA sequencer. The 16S rDNA sequences were aligned with sequences currently available from the public databases. Evolutionary distances were calculated by the method of Jukes and Cantor (11). A phylogenetic dendrogram was constructed from the distance matrices by using the algorithm of De Soete (1).

Nucleotide sequence accession numbers. The EMBL accession numbers for the $16 \mathrm{~S}$ rDNA sequences of $N$. amarae DSM $43392^{\mathrm{T}}, R$. aichiensis DSM $43978^{\mathrm{T}}$, Gordona bronchialis DSM $43247^{\mathrm{T}}$, Gordona rubropertincta DSM $43197^{\mathrm{T}}$, Gordona sputi DSM $43896^{\mathrm{T}}$, and Gordona terrae DSM $43249^{\mathrm{T}}$ are X80635, X80633, X79287, X80632, X80634, and X79286, respectively.

\section{RESULTS AND DISCUSSION}

The results of this study and previous chemotaxonomic analyses of $N$. amarae DSM $43392^{\mathrm{T}}$ and $R$. aichiensis DSM $43978^{\mathrm{T}}$ are shown in Table 1 along with data for other related taxa. The cell walls of $R$. aichiensis DSM $43978^{\mathrm{T}}$ contained arabinose and galactose as major cell wall sugars, mesodiaminopimelic acid as the only diamino acid, and $N$-glycolated muramic acid moieties of peptidoglycan. The polar lipids included diphosphatidylglycerol, phosphatidylglycerol, phosphatidylinositol, phosphatidylinositol mannosides, and phosphoethanolamine, and $\mathrm{MK}-9\left(\mathrm{H}_{2}\right)$ was found to be the predom- 
TABLE 1. Chemosystematic characteristics of $N$. amarae (Lechevalier and Lechevalier), R. aichiensis (Tsukamura), and related wall chemotype IV taxa containing mycolic acids ${ }^{a}$

\begin{tabular}{|c|c|c|c|c|c|}
\hline Taxon & $\begin{array}{l}\text { Fatty acid } \\
\text { composition }{ }^{b}\end{array}$ & $\begin{array}{c}\text { Mycolate size } \\
\text { (no. of carbon atoms) }\end{array}$ & $\begin{array}{c}\text { Presence of } \\
\text { phosphatidylethanolamine }\end{array}$ & Major menaquinone(s) & $\begin{array}{l}\mathrm{G}+\mathrm{C} \text { content of } \\
\text { DNA (mol\%) }\end{array}$ \\
\hline R. aichiensis & $\mathrm{S}, \mathrm{U}, \mathrm{T}$ & $56-66$ & + & MK- $9\left(\mathrm{H}_{2}\right)$ & 65 \\
\hline N. amarae & $\mathrm{S}, \mathrm{U}, \mathrm{T}$ & $46-54$ & + & MK-9 $\left(\mathrm{H}_{2}\right)$ & $60-66$ \\
\hline Gordona species & $\mathrm{S}, \mathrm{U}, \mathrm{T}$ & $48-66$ & + & MK-9 $\left(\mathrm{H}_{2}\right)$ & $63-69$ \\
\hline Nocardia species & $\mathrm{S}, \mathrm{U}, \mathrm{T}$ & $44-60$ & + & MK-8( $\left(\mathrm{H}_{4}, \omega-\mathrm{cycl}\right)$ & $64-72$ \\
\hline Rhodococcus species & $\mathrm{S}, \mathrm{U}, \mathrm{T}$ & $34-52$ & + & $\mathrm{MK}-8\left(\mathrm{H}_{2}\right)$ & $63-73$ \\
\hline Tsukamurella species & $\mathrm{S}, \mathrm{U}, \mathrm{T}$ & $64-68$ & + & MK-9 & $67-68$ \\
\hline Mycobacterium species & S, U,T & $60-90$ & + & MK- $9\left(\mathrm{H}_{2}\right)$ & $62-70$ \\
\hline Corynebacterium species & $\mathrm{S}, \mathrm{U}^{d}$ & $22-36$ & $v^{e}$ & 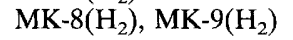 & $51-67$ \\
\hline
\end{tabular}

${ }^{a}$ Adapted from the studies of Goodfellow $(3,4)$ and Stackebrandt et al. (25).

${ }^{b} \mathrm{~S}$, saturated; $\mathrm{U}$, monounsaturated; $\mathrm{T}$, tuberculostearic acid.

$c+$, present; $v$, variable.

${ }^{d}$ Tuberculostearic acid is also present in Corynebacterium ammoniagenes, Corynebacterium bovis, Corynebacterium cystitidis, Corynebacterium minutissimum, Corynebacterium pilosum, Corynebacterium urealyticum, and Connebacterium variabilis $(9,13,20)$

${ }^{e}$ Phosphatidylethanolamine is also present in C. ammoniagenes, C. bovis, C. cystitidis, Corynebacterium pseudodiphtheriticum, and $C$. urealyticum (9, 20).

inant menaquinone, which is in good agreement with previous results (6). An analysis of the simple fatty acids obtained from whole-cell methanolysates revealed a pattern consisting of straight-chain, saturated and unsaturated fatty acids with significant amounts of tuberculostearic acid (10-methyl octadecanoic acid) (Table 2). The wall chemotype of both $N$. amarae DSM $43392^{\mathrm{T}}$ and $R$. aichiensis DSM $43978^{\mathrm{T}}$ is the characteristic wall chemotype IV (sensu Lechevalier and Lechevalier [15]) found in genera containing mycolic acids, but these two strains differ significantly in menaquinone composition [having predominantly MK-9 $\left(\mathrm{H}_{2}\right)$ and minor amounts of MK-8 $\left.\left(\mathrm{H}_{2}\right)\right]$ from the genera to which they are currently assigned, namely, the genera Nocardia [MK- $8\left(\mathrm{H}_{4}, \omega\right.$-cycl $\left.)\right]$ and Rhodococcus [MK-8 $\left(\mathrm{H}_{2}\right)$ ]. Furthermore, the sizes of the mycolic acids of $R$. aichiensis DSM $43978^{\mathrm{T}}$ and N. amarae DSM $43392^{\mathrm{T}}$ are similar to the sizes of the mycolic acids found in members of the genus Gordona $(3,29)$ (Table 1), although pyrolytic cleavage of methyl mycolates of $N$. amarae DSM $43392^{\mathrm{T}}$ releases unusual monounsaturated esters $(5,16)$ that are unique to this species within the family Nocardiaceae. Nevertheless, as shown in Table 1, the combined chemotaxonomic characteristics of $R$. aichiensis DSM $43978^{\mathrm{T}}$ and $N$. amarae DSM $43392^{\mathrm{T}}$ suggest that these organisms are closely related to the genus Gordona (25). Therefore, almost complete 16S rDNA sequences $(>1,500$ nucleotides) were determined for $N$. amarae DSM $43392^{\mathrm{T}}, R$. aichiensis DSM $43978^{\mathrm{T}}, G$. bronchialis DSM $43247^{\mathrm{T}}$,

TABLE 2. Fatty acid compositions of $R$. aichiensis and G. sputi

\begin{tabular}{lcr}
\hline \multirow{2}{*}{ Fatty acid } & \multicolumn{2}{c}{$\%$ in: } \\
\cline { 2 - 3 } & R. aichiensis & G. sputi \\
\hline $10: 0$ & 1.18 & 0.91 \\
i-3-OH-11:0 & 1.72 & 1.53 \\
$14: 0$ & 1.64 & 2.56 \\
$15: 0$ & 1.45 & 2.36 \\
$16: 1(\omega 6)$ & 18.05 & $-{ }^{a}$ \\
$16: 0$ & 28.92 & 43.19 \\
$17: 1(\omega 8)$ & 1.68 & 0.85 \\
$17: 0$ & 1.56 & 1.51 \\
$10-$ Me-17:0 & 0.87 & - \\
$18: 1(\omega 9)$ & 17.51 & 27.96 \\
$18: 0$ & - & 1.94 \\
TBSA (10-Me-18:0) & - & 16.51 \\
\hline${ }^{a}-$, not detected. & 24.06 & \\
${ }^{b}$ TBSA, tuberculostearic acid. & &
\end{tabular}

G. rubropertincta DSM $43197^{\mathrm{T}}$, G. sputi DSM $43896^{\mathrm{T}}$, and $G$. terrae DSM $43249^{\mathrm{T}}$. The phylogenetic dendrogram (in Fig. 1) shows the relationships of $R$. aichiensis DSM $43978^{\mathrm{T}}$ and $N$. amarae DSM $43392^{\mathrm{T}}$ to some members of related genera for which sequence data are available. The results of a comparison of sequence data for all Gordona species and related organisms are shown in Table 3; the genus Gordona was found to be phylogenetically coherent and was clearly distinct from other actinomycete genera (Fig. 1). In addition, both $R$. aichiensis DSM $43978^{\mathrm{T}}$ and $N$. amarae DSM $43392^{\mathrm{T}}$ were found to cluster with strains belonging to the genus Gordona. This close relationship was also observed in the rDNA similarity values shown in Table 3. The levels of similarity between $N$. amarae DSM $43392^{\mathrm{T}}$ and members of the genus Gordona ranged from 96.9 to $97.8 \%$, while the levels of similarity to members of other genera were less than $94.4 \%$. In the case of $R$. aichiensis DSM $43978^{T}$ an extremely high level of similarity $(99.7 \%)$ to G. sputi DSM $43896^{\mathrm{T}}$ was observed, although the level of

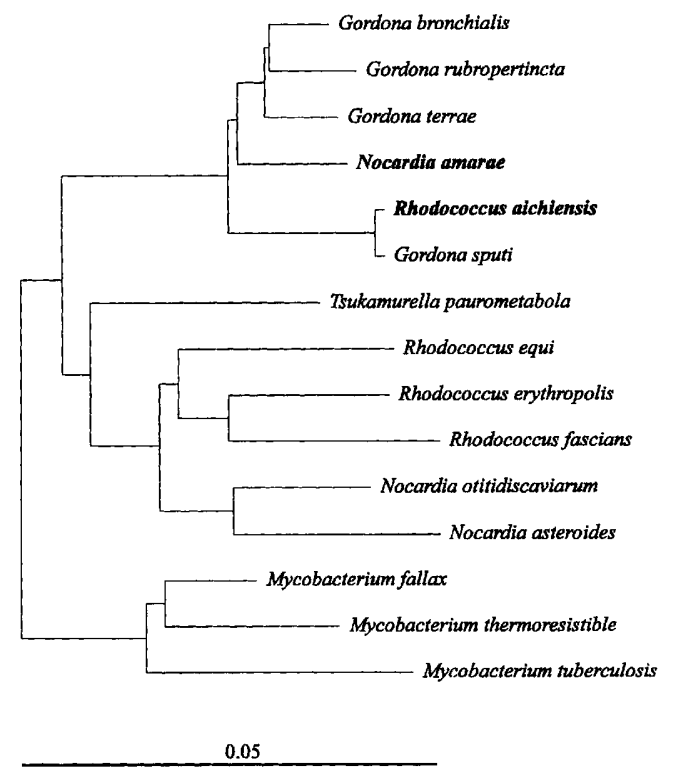

FIG. 1. Phylogenetic dendrogram indicating the relationships of $R$. aichiensis and $N$. amarae to members of the genus Gordona and related taxa. $\mathrm{Bar}=5$ substitutions per 100 nucleotides. 
TABLE 3. 16S rDNA similarity values for organisms used in this study

\begin{tabular}{|c|c|c|c|c|c|c|c|c|c|c|c|c|c|c|}
\hline \multirow[b]{2}{*}{ Species } & \multicolumn{14}{|c|}{$\% 16 \mathrm{~S}$ rDNA similarity with: } \\
\hline & 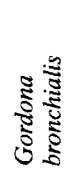 & 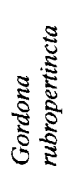 & 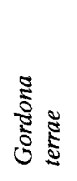 & 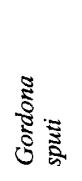 & 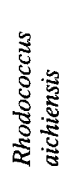 & 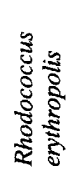 & 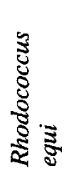 & 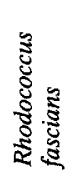 & 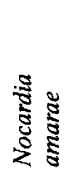 & 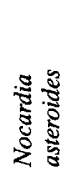 & 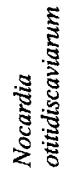 & 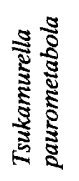 & 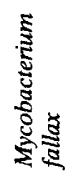 & 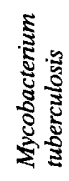 \\
\hline \multicolumn{15}{|l|}{ Gordona bronchialis } \\
\hline Gordona rubropertincta & 98.3 & & & & & & & & & & & & & \\
\hline Gordona terrae & 98.3 & 98.1 & & & & & & & & & & & & \\
\hline Gordona sputi & 97.2 & 96.4 & 96.6 & & & & & & & & & & & \\
\hline Rhodococcus aichiensis & 97.3 & 96.7 & 96.7 & 99.7 & & & & & & & & & & \\
\hline Rhodococcus erythropolis & 93.5 & 93.3 & 93.4 & 93.0 & 92.9 & & & & & & & & & \\
\hline Rhodococcus equi & 93.7 & 93.8 & 93.9 & 92.5 & 92.6 & 95.2 & & & & & & & & \\
\hline Rhodococcus fascians & 92.9 & 93.0 & 93.2 & 91.9 & 92.0 & 95.8 & 94.7 & & & & & & & \\
\hline Nocardia amarae & 97.5 & 97.4 & 97.8 & 96.9 & 97.0 & 93.4 & 93.3 & 92.6 & & & & & & \\
\hline Nocardia asteroides & 93.0 & 93.0 & 93.0 & 92.2 & 92.3 & 94.2 & 94.4 & 93.4 & 92.8 & & & & & \\
\hline Nocardia otitidiscaviarum & 93.7 & 93.6 & 93.8 & 92.4 & 92.5 & 94.7 & 95.6 & 94.7 & 92.9 & 96.1 & & & & \\
\hline Tsukamurella paurometabola & 93.6 & 93.5 & 93.5 & 93.7 & 93.6 & 94.6 & 94.0 & 93.7 & 94.4 & 93.6 & 93.9 & & & \\
\hline Mycobacterium fallax & 93.7 & 93.2 & 93.7 & 93.7 & 94.0 & 93.4 & 93.1 & 93.1 & 93.7 & 93.2 & 94.0 & 94.8 & & \\
\hline Mycobacterium tuberculosis & 92.8 & 91.8 & 92.6 & 91.6 & 91.7 & 91.3 & 91.3 & 92.0 & 92.1 & 91.0 & 92.8 & 92.5 & 96.1 & \\
\hline Mycobacterium thermoresistible & 93.0 & 92.3 & 93.0 & 93.6 & 93.5 & 92.5 & 92.1 & 91.7 & 93.3 & 92.1 & 92.9 & 93.5 & 97.1 & 94.6 \\
\hline
\end{tabular}

DNA-DNA relatedness between these species was found to be only 38 and $40 \%$ when the level was determined by the nitrocellulose filter and spectrophotometric methods, respectively $(13,30)$. $R$. aichiensis DSM $43978^{\mathrm{T}}$ and $G$. sputi DSM $43896^{\mathrm{T}}$ can be differentiated not only by DNA relatedness data but also by fatty acid data (Table 2 ) and phenotypic properties (Table 4). Obvious discrepancies between DNA-DNA hybridization results and levels of $16 \mathrm{~S}$ rRNA sequence similarity have also been reported previously (2), thus strongly emphasizing the fact that a polyphasic approach is highly recommended for the establishment of new genospecies.

In conclusion, the combined chemosystematic and phylogenetic data indicate that $N$. amarae DSM $43392^{\mathrm{T}}$ and $R$. aichiensis DSM $43978^{\mathrm{T}}$ are closely related to the genus Gor- dona. On the basis of the data presented here we propose that $N$. amarae DSM $43392^{\mathrm{T}}$ and $R$. aichiensis DSM $43978^{\mathrm{T}}$ should be transferred to the genus Gordona as Gordona amarae and Gordona aichiensis, respectively. The species descriptions are emended accordingly below to incorporate the data obtained in this study.

Description of Gordona amarae (Lechevalier and Lechevalier) comb. nov. The species description below is based on information obtained from several sources, including references 5, 16, and 17 and our own observations.

Convoluted tannish to white colonies with filamentous margins are formed on various media. There is sparse aerial mycelium which is not visible macroscopically. The substrate mycelium consists of moderately branching vegetative hyphae

TABLE 4. Diagnostic characteristics of Gordona species

\begin{tabular}{|c|c|c|c|c|c|c|}
\hline Characteristic & G. aichiensis & G. amarae & G. bronchialis & G. rubropertincta & G. sputi & G. terrae \\
\hline Colony color white to $\tan ^{a}$ & $-{ }^{b}$ & + & - & - & - & - \\
\hline \multicolumn{7}{|l|}{ Cleavage of the following 7 -amino-4-methylcoumarin substrates ${ }^{c}$ : } \\
\hline D-Alanine-amino-4-methylcoumarin & + & ND & - & + & - & + \\
\hline Isoleucine-7-amino-4-methylcoumarin & + & ND & - & - & + & - \\
\hline Pyroglutamate-7-amino-4-methylcoumarin & - & ND & - & - & - & + \\
\hline Valine-7-amino-4-methylcoumarin & + & ND & - & + & + & + \\
\hline \multicolumn{7}{|l|}{ Growth on the following sole carbon sources ${ }^{d}$ : } \\
\hline D-Galactose $(1.0 \%, \mathrm{wt} / \mathrm{vol})$ & + & - & - & + & + & + \\
\hline meso-Inositol $(1.0 \%, \mathrm{wt} / \mathrm{vol})$ & - & + & + & - & - & - \\
\hline Raffinose $(1.0 \%, \mathrm{wt} / \mathrm{vol})$ & - & $t^{e}$ & - & - & + & + \\
\hline L-Rhamnose $(1.0 \%, \mathrm{wt} / \mathrm{vol})$ & - & + & - & - & - & + \\
\hline Citric acid (Na salt) $(0.1 \%$, wt/vol $)$ & + & - & - & + & - & + \\
\hline \multicolumn{7}{|l|}{ Mycolic acids: } \\
\hline Avg carbon no. & 62 & $50-52$ & 64 & $58-59$ & $61-62$ & 58 \\
\hline FAME released upon pyrolysis of MAME $^{g}$ & $16: 0$ & $16: 1,18: 1$ & 18:0 & $16: 0,18: 0$ & $16: 0,18: 0$ & $16: 0,18: 0$ \\
\hline $16: 1$ fatty acid present $f$ & $+^{h}$ & + & + & + & $-h$ & + \\
\hline
\end{tabular}

${ }^{a}$ Data from references 5 and 16.

${ }^{b}-, \geq 90 \%$ of the strains are negative;,$+ \geq 90 \%$ of the strains are positive; ND, not determined.

${ }^{c}$ Data from references 5,7 , and 8 .

${ }^{d}$ Data from references $5,7,8$, and 16 .

The concentration used to determine raffinose utilization was $0.2 \%$ (wt/vol) (12)

${ }^{f}$ Data from references 5,13 , and 29 and this study.

${ }^{g}$ FAME, fatty acid methyl esters; MAME, mycolic acid methyl esters

${ }^{h}$ Data for $G$. sputi DSM $43896^{\mathrm{T}}$ and $G$. aichiensis DSM $43978^{\mathrm{T}}$. 
that grow into the agar medium and do not fragment in undisturbed cultures. Secondary branching is rare. Filaments are gram positive and partially acid fast. Hydrolyzes esculin, Tween 20, Tween 40, Tween 60 , and urea but not casein, elastin, gelatin, hypoxanthine, adenine, tyrosine, or xanthine.

Catalase positive and $p$-nitrophenoloxidase and $m$-nitrophenoloxidase negative. Reduces nitrate to nitrite.

Grows on ethanol, fructose, glycerol, maltose, D-mannose, D-mannitol, L-rhamnose, salicin, sucrose, trehalose, adipate, pimelic acid, sebacic acid, acetate, fumarate, gluconate, lactate, malate, propionate, pyruvate, and succinate as sole carbon sources, but not on ribitol, L-arabinose, cellobiose, lactose, melezitose, raffinose, D-glucitol, D-xylose, testosterone, L-tyrosine, acetamide, benzamide, benzoate, citrate, $p$-cresol, $m$ hydroxybenzoate, oxalate, and tartrate. Does not utilize serine and trimethylenediamine as sole carbon and nitrogen sources.

Acid is produced from fructose, glucose, glycerol, inositol, maltose, D-mannitol, D-mannose, L-rhamnose, salicin, sucrose, and trehalose but not from ribitol, L-arabinose, cellobiose, galactitol, D-galactose, lactose, melibiose, $\alpha$-methyl-D-glucoside, raffinose, D-glucitol, D-xylose, or $\beta$-methyl-D-xyloside.

Susceptible to lysozyme broth, penicillin (10 IU), phenol $(0.1 \%$, wt/vol $)$, phenyl ethanol $(0.3 \%$, wt/vol $)$, and sodium chloride ( 5 and $7 \%$, wt/vol) but not crystal violet $(0.0001$ and $0.001 \%$, wt $/ \mathrm{vol})$, phenol $(0.01 \%$, wt $/ \mathrm{vol})$ or sodium azide $(0.01 \%, \mathrm{wt} / \mathrm{vol})$.

Grows at 23 to $37^{\circ} \mathrm{C}$, but not at 10 or $40^{\circ} \mathrm{C}$.

The cell wall chemotype is wall chemotype IV, with mesodiaminopimelic acid as the only diamino acid and arabinose and galactose as major cell wall sugars. The predominant isoprenolog is $\mathrm{MK}-9\left(\mathrm{H}_{2}\right)$. The polar lipids include phosphatidylethanolamine, diphosphatidylglycerol, phosphatidylglycerol, phosphatidylinositol, and phosphatidylinositol mannosides. Contains major amounts of straight-chain, saturated and unsaturated fatty acids and tuberculostearic acid (2\% 14:0, 8\% 16:1, 43\% 16:0, $21 \%$ 18:1, 18\% 18:0, 8\% 10-Me-18:0). Mycolic acids with 46 to 54 carbons and up to three double bonds are present. Upon pyrolysis gas chromatography of mycolates 16:0, 18:0, 16:1, and 18:1 fatty acid esters are released.

The $\mathrm{G}+\mathrm{C}$ content of the DNA is 60 to $66 \mathrm{~mol} \%$.

The type strain is SE6 (= DSM 43392), as described by Lechevalier and Lechevalier (16).

Description of Gordona aichiensis (Tsukamura) comb. nov. The species description below is based on our data and additional information obtained from several sources, including references $3,27,29$, and 30 .

Gram-positive, nonmotile short rods that grow amycelially and have a rod-coccus cycle. Rough pinkish or orange colonies are formed on egg media. Hydrolyzes Tween 80 and reduces nitrate to nitrite. Acetamidase, urease, nicotinamidase, pyrazinamidase, and valine arylamidase positive, but allantoinase, benzamidase, isonicotinamidase, salycinamidase, succinamidase, and valine arylamidase negative. Acid phosphatase and $\alpha$-glucosidase positive, but arylsulfatase, $\alpha$-esterase, $\beta$-esterase, and $\beta$-galactosidase negative.

Uses glutamate, acetamide, and monoethanolamine as sole carbon and nitrogen sources, but does not use serine, glucosamine, benzamide, and trimethylene diamine.

Utilizes acetate, citrate, succinate, malate, pyruvate, fumarate, $p$-hydroxybenzoate, pimelate, ethanol, 1-propanol, 1-butanol, isobutanol, butane-2-3-diol, D-glucose, D-fructose, lactose, sucrose, D-mannose, and trehalose as sole carbon sources, but does not utilize benzoate, citraconate, D-mandelate, malonate, glutamate, L-arabinose, D-galactose, L-rhamnose, D-xylose, inositol, D-mannitol, D-glucitol, propylene glycol, 1,3-, 1,4-, and 2,3-butylene glycols, andosterone, and testosterone.
Grows at 28,37 , and $42^{\circ} \mathrm{C}$, but not at $45^{\circ} \mathrm{C}$

Resistant to picric acid $(0.2 \%$, wt/vol $)$, sodium nitrite $(0.1 \%$, $\mathrm{wt} / \mathrm{vol})$, and sodium salicylate $(0.1 \%$, wt/vol $)$, but not mitomycin $\mathrm{C}(5 \mu \mathrm{g} / \mathrm{ml})$ and 5-fluorouracil $(20 \mu \mathrm{g} / \mathrm{ml})$.

The cell wall chemotype is wall chemotype IV, with mesodiaminopimelic acid as the only diamino acid and arabinose and galactose as major cell wall sugars. The predominant isorenolog is MK-9 $\left(\mathrm{H}_{2}\right)$; minor amounts of MK- $8\left(\mathrm{H}_{2}\right)$ are also present. The polar lipids include phosphatidylethanolamine, diphosphatidylglycerol, phosphatidylglycerol, phosphatidylinositol, and phosphatidylinositol mannosides. Contains major amounts of straight-chain, saturated and unsaturated fatty acids and tuberculostearic acid. Mycolic acids with 56 to 66 carbons and up to six double bonds are present. Upon pyrolysis gas chromatography of mycolates 16:0 and 18:0 fatty acid esters are liberated.

The $\mathrm{G}+\mathrm{C}$ content of the DNA is $65 \mathrm{~mol} \%$.

Isolated from human sputum.

The type strain is E9028 (= DSM 43978), as described by Tsukamura (27).

\section{REFERENCES}

1. De Soete, G. 1983. A least squares algorithm for fitting additive trees to proximity data. Psychometrika 48:621-626.

2. Fox, G. E., J. D. Wisotzkey, and P. Jurtshuk, Jr. 1992. How close is close: 16S rRNA sequence identity may not be sufficient to guarantee species identity. Int. J. Syst. Bacteriol. 42:166-170.

3. Goodfellow, M. 1989. Genus Rhodococcus Zopf 1891 , p. $2362-$ 2371. In S. T. Williams, M. E. Sharpe, and J. G. Holt (ed.), Bergey's manual of systematic bacteriology, vol. 4. Williams and Wilkins, Baltimore.

4. Goodfellow, M. 1992. The family Nocardiaceae, p. 1188-1213. In A. Balows, H. G. Trüper, M. Dworkin, W. Harder, and K. H. Schleifer (ed.), The prokaryotes, 2nd ed. Springer-Verlag, New York.

5. Goodfellow, M., D. E. Minnikin, C. Todd, G. Alderson, S. M. Minnikin, and M. D. Collins. 1982. Numerical and chemical classification of Nocardia amarae. J. Gen. Microbiol. 128:12831297.

6. Goodfellow, M., E. G. Thomas, and A. L. James. 1987. Characterisation of rhodococci using peptide hydrolase substrates based on 7-amino-4-methylcoumarin. FEMS Microbiol. Lett. 44:349-355.

7. Goodfellow, M., E. G. Thomas, A. C. Ward, and A. L. James. 1990. Classification and identification of rhodococci. Zentralbl. Bakteriol. 274:299-315.

8. Goodfellow, M., J. Zakrzewska-Czerwinska, E. G. Thomas, M. Mordarski, A. C. Ward, and A. L. James. 1991. Polyphasic taxonomic study of the genera Gordona and Tsukamurella including the description of Tsukamurella wratislaviensis sp. nov. Zentralbl. Bakteriol. 275:162-178.

9. Herrera-Alcaraz, E. A., P. L. Valero-Guillén, F. Martin-Luengo, and F. Soriano. 1990. Taxonomic implications of the chemical analysis of the D2 group of corynebacteria. FEMS Microbiol. Lett. 72:341-344.

10. Howarth, O. W., E. Grund, R. M. Kroppenstedt, and M. D. Collins. 1986. Structural determination of a new naturally occuring cyclic vitamin K. Biochem. Biophys. Res. Commun. 140:916923.

11. Jukes, T. H., and C. R. Cantor. 1969. Evolution of protein molecules, p. 21-132. In H. N. Munro (ed.), Mammalian protein metabolism. Academic Press, New York.

12. Kämpfer, P., W. Dott, and R. M. Kroppenstedt. 1990. Numerical classification and identification of some nocardioform bacteria. J. Gen. Appl. Microbiol. 36:309-391.

13. Klatte, S., and R. M. Kroppenstedt. Unpublished data.

14. Kothe, H. W., G. Vobis, R. M. Kroppenstedt, and A. Henssen. 1989. A taxonomic study of mycolateless, wall chemotype IV actinomycetes. Syst. Appl. Microbiol. 12:61-69.

15. Lechevalier, H. A., and M. P. Lechevalier. 1970. Chemical composition as a criterion in the classification of aerobic actinomycetes. Int. J. Syst. Bacteriol. 20:435-444. 
16. Lechevalier, M. P., and H. A. Lechevalier. 1974. Nocardia amarae sp. nov., an actinomycete common in foaming activated sludge. Int. J. Syst. Bacteriol. 24:278-288.

17. Mordarski, M., M. Goodfellow, A. Tkacz, and I. Kaszen. 1977. Comparison of DNA homology in Nocardia amarae, N. autotrophica and Rhodococcus strains. Biol. Actinomycetes Relat. Org. 12:21-26.

18. Mordarski, M., M. Goodfellow, A. Tkacz, G. Pulverer, and K. P. Schaal. 1980. Ribosomal ribonucleic acid similarities in the classification of Rhodococcus and related taxa. J. Gen. Microbiol. 118:313-319.

19. Orchard, V. A., and M. Goodfellow. 1980. Numerical classification of some named strains of Nocardia asteroides and related isolates from soil. J. Gen. Microbiol. 118:295-312.

20. Pitcher, D., A. Soto, F. Soriano, and P. Valero-Guillén. 1992. Classification of coryneform bacteria associated with human urinary tract infection (group D2) as Corynebacterium urealyticum sp. nov. Int. J. Syst. Bacteriol. 42:178-181.

21. Rainey, F. A., M. Dorsch, H. W. Morgan, and E. Stackebrandt. 1992. 16S rDNA analysis of Spirochaeta thermophila: position and implications for the systematics of the order Spirochaetales. Syst. Appl. Microbiol. 16:224-226.

22. Ridell, M. 1984. Serotaxonomical analysis of strains referred to Nocardia amarae and Rhodococcus equi. Zentralbl. Bakteriol. Parasitenkd. Infektionskr. Hyg. Abt. 1 Orig. Reihe A 258:492-497.

23. Springer, B., P. Kirschner, G. Meyer-Rost, K.-H. Schröder, R. M. Kroppenstedt, and E. C. Böttger. 1993. Mycobacterium interjectum, a new species isolated from a patient with chronic lymphadenitis. J. Clin. Microbiol. 31:3083-3089.

24. Stackebrandt, E., W. Ludwik, E. Seewaldt, and K. H. Schleifer.
1983. Phylogeny of sporeforming members of the order Actinomycetales. Int. J. Syst. Bacteriol. 33:173-180.

25. Stackebrandt, E., J. Smida, and M. D. Collins. 1988. Evidence of phylogenetic heterogeneity within the genus Rhodococcus: revival of the genus Gordona (Tsukamura). J. Gen. Appl. Microbiol. 34: 341-348.

26. Stackebrandt, E., and C. R. Woese. 1981 . Towards a phylogeny of the actinomycetes and related organisms. Curr. Microbiol. 5:197202.

27. Tsukamura, M. 1982 . Numerical analysis of the taxonomy of nocardiae and rhodococci. Division of Nocardia asteroides sensu strictu into two species and description of Nocardia paratuberculosis sp. nov. Tsukamura (formerly the Kyoto-I group of Tsukamura), Nocardia nova sp. nov. Tsukamura, Rhodococcus aichiensis sp. nov. Tsukamura, Rhodococcus chubuensis sp. nov. Tsukamura, and Rhodococcus obuensis sp. nov. Tsukamura. Microbiol. Immunol. 26:1101-1119.

28. Williams, D. R., E. M. H. Wellington, and L. S. Tipler. 1980. The taxonomic implications of the reactions of representative Nocardia strains to actinophages. J. Gen. Microbiol. 119:173-178.

29. Yano, I., I. Tomiyasu, K. Kaneda, and S. Imaizumi. 1986. GC/MS analysis of mycolic acid molecular species and contribution to the chemotaxonomy of new Rhodococcus species, p. 567-570. In G. Szabó, S. Biró, and M. Goodfellow (ed.), Biological, biochemical and biomedical aspects, of actinomycetes, part B. Académiai, Kiadó, Budapest.

30. Zakrzewska-Czerwinska, J., M. Mordarski, and M. Goodfellow. 1988. DNA base composition and homology values in the classification of some Rhodococcus species. J. Gen. Microbiol. 134: 2807-2813. 